\title{
Forest management practice determines whether the Amazon basin remains a globally important sink for mercury
}

MARTIN JISKRA ${ }^{1}$, JAGANNATH BISWAKARMA ${ }^{2}$ AND PASQUALE BORRELLI ${ }^{3}$

${ }^{1}$ University of Basel

${ }^{2}$ Eawag

${ }^{3}$ University of Pavia

Presenting Author: martin.jiskra@unibas.ch

Terrestrial ecosystems are an important sink for atmospheric mercury $(\mathrm{Hg})$, thereby reducing the burden of anthropogenic $\mathrm{Hg}$ emissions to global Oceans. Forests in the Amazon basin account for $15 \%$ of global photosynthesis and $21 \%$ atmospheric $\mathrm{Hg}$ deposition to land. The expansion of agriculture has led to deforestation of $18^{\prime} 000 \mathrm{~km}^{2} \mathrm{yr}^{-1}$ on average over the past 3 decades and $40 \%$ to total forest area is expected to be lost by 2050. Here, we assess the effect of deforestation on the terrestrial-atmosphere net exchange of $\mathrm{Hg}$ and on $\mathrm{Hg}$ transfer to aquatic ecosystems. Our results show, that in 2020 the Amazon basin accumulated $217 \mathrm{Mg} \mathrm{y}^{-1} \mathrm{Hg}$ from the atmosphere and 70 $\mathrm{Mg} \mathrm{y}^{-1}$ were transferred to surface water. If deforestation continues at current rates, the Amazon basin may turn from a net sink to a net $\mathrm{Hg}$ source by 2040 . This $\mathrm{Hg}$ burden could be reduced by implementing forest conservation strategies, with the "best management practice" scenario continuing to accumulate $94 \mathrm{Mg} \mathrm{y}^{-1}$ in 2050. This study shows that land-use change can have irreversible effects on global and local mercury dynamics and illustrates the potential of land-use policy to address global mercury pollution. 